\title{
Classic hairy cell leukemia
}

INSERM

\section{Source}

INSERM. (1999). Orphanet: an online rare disease and orphan drug data base. Classic hairy cell leukemia. ORPHA:58017

Hairy cell leukemia $(\mathrm{HCL})$ is a rare type of leukemia in which abnormal B-lymphocytes are present in the bone marrow, spleen and peripheral blood. It is a slowly progressive chronic lymphocytic leukemia (CLL). The name comes from the abnormally shaped lymphocytes with hair-like projections. 